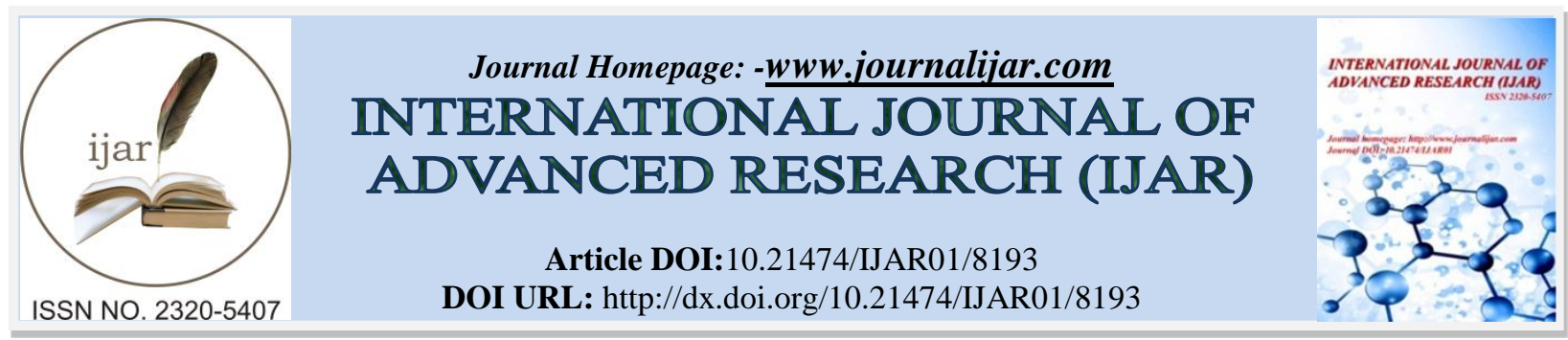

RESEARCH ARTICLE

\title{
GOWIN DIAGRAM MEASURED BY PEDAGOGICAL WORKSHOP IN THE SCIENCE FAIR CONTEXT.
}

\author{
Lucas Antonio Xavier ${ }^{1}$ and Breno Rodrigues Segatto ${ }^{2}$. \\ 1. Master, Department of Physics - UFES, Brazil. \\ 2. Teacher, Department of Physics - UFES, Brazil.
}

\section{Manuscript Info}

Manuscript History

Received: 10 October 2018

Final Accepted: 12 November 2018

Published: December 2018

Key words:Diagram, Science Fair,Active Methodology, Physics.
Pedagogical Workshop, Gowin

\section{Abstract}

The State School of Elementary and High School levels Teacher Filomena Quitiba, located in the municipality of Piúma-ES, has a history of 35 years of annual Science Fair, which has sought to engage students and teachers of Basic Education. The present article presents a methodological approach of the scientific method through the use of Gowin Diagram for the development of experiments for Science Fairs with the realization of Pedagogical Workshops. The proposed use of this heuristic instrument, due to its usability in the experimental context, is to promote the rupture of practices of traditional scripts. Two pedagogical workshops were designed and offered for regular high school students in order to immerse these students in the new method. After the workshops were carried out activities to promote greater familiarity with the new tool. This article presents results about the promising Pedagogical Workshops, since of the 78 projects submitted at the Science Fair of 2018, 10 used the Gowin Diagram. It can be inferred that these students began to realize the importance of the dynamics of the Gowin Diagram as a guiding instrument for the experiments developed for the Science Fair and for explaining them to the visiting public.

Copy Right, IJAR, 2017,. All rights reserved.

\section{Introduction:-}

The Science Fair is a practice developed at the Prof. ${ }^{a}$ Filomena Quitiba School, from a project methodology perspective and, according to Rosa (1995), "regular experimental activity, incorporated into the teaching of an organic form is an essential condition for an effective activity in science fair". The purpose of the event is to socialize with the local community the projects prepared by the students.

In accordance with the guidelines of the Ministry of Education:

Science fairs are social, scientific and cultural events held in schools or in the community with the intention of, during the student's presentation, to facilitate a dialogue with visitors, constituting the opportunity to discuss knowledge, methodologies research and creativity of the students in all aspects related to the exhibition of works (BRASIL, 2006, p. 20).

\section{Corresponding Author:-Lucas Antonio Xavier.}

Address:- Master, Department of Physics - UFES, Brazil. 
In addition, according to Rosa (1995), "the success of the fair is a motivational and significant ingredient for students and teachers". Thus, the taste for science, provided by experimental activity, can be developed through a methodology that encompasses various skills. For Mortimer and Scott (2002, p. 7), "we must overcome the idea of science that is easy, simple and in continuity with common sense, to enter into the culture of scientists implies knowing another way of thinking, speaking and explaining the everyday world. "It is essential that the student knows the path of science and its method, in this perspective a new element was introduced to correct these difficulties, it is Gowin's heuristic (1981), also called Diagram V, Gowin Diagram, See Gowin, among others, it offers a reference system capable of contributing to the improvement of teaching.

The Gowin Diagram (1984) illustrated in Figure 1, which is the mimicry of the scientific method, has four interconnected parts: in the center, the issue-focus, at the vertex, the event, on the left, the conceptual domain (thinking) and the right side, the methodological domain (doing).

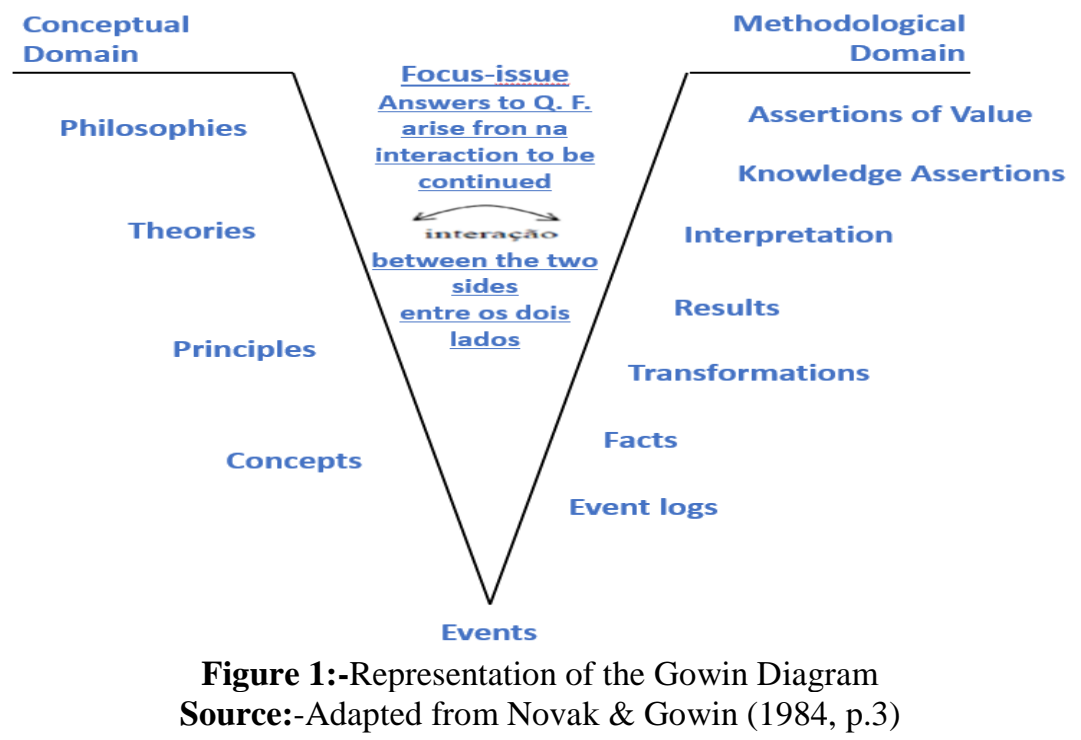

The focus-issue aims to mobilize the learner for scientific research.The event consists of two elements: instruments used in scientific research and the procedure, which are the steps for carrying out the research. The conceptual domain (thinking) is divided into philosophies, theories, principles and concepts. This set is part of the scientific method and is adopted by the scientific community. As well as, the methodological domain (doing), divided into registers of events, events, transformations, results, measurements, interpretations, assertions of knowledge and value. Ferracioli $(2005 ; 2018)$ argues "the diagram can be understood as a methodological instrument to guide both the research process and an instrument for analysis, interpretation and evaluation of data from a study".

The inclusion of the heuristic instrument emerges as an alternative budget to an existing problem in the preparation of the students for the Science Fair. Therefore, the questioning arises: In what way do students better understand the scientific concepts involved in the experiments? The general objective of the research is to analyze the use of the Gowin Diagram as an instructive element for the Science Fair. In order to respond to the objective, specific objectives are chosen: Offer pedagogical workshops to train the students and adopt the diagram as a facilitating instrument for learning physics.

\section{Methodological aspects:-}

The research work is framed in the qualitative research referential initiated in March 2018 and concluded in August of the same year in the school of the state network Prof. ${ }^{a}$ Filomena Quitiba, located in Piúma / ES. The option for the region was made because of the local lack of research. The school has a history of 35 years of conducting Science Fair and the subjects of the research were 136 students of six classes from the regular Middle School series for the sample. Subsequently, the students answered a questionnaire containing 15 questions in order to obtain information about the use of Diagram V in the Science Fair with the purpose of improving the educational service. 


\section{Pedagogical Workshops of the Gowin Diagram:-}

The inclusion of the Gowin Diagram in the Science Fair came to elude our problems and the path taken was through workshops, which, in the words of Anastasiou and Alves (2004),

It is characterized as a strategy of pedagogical making where the space of construction and reconstruction of knowledge are the main emphases. It is a place to think, discover, reinvent, create and recreate, favored by the horizontal form in which the human relationship occurs. (ANASTASIOU AND ALVES, 2004, p. 95)

The workshop is a resource of great potential to familiarize the culture of the Gowin Diagram. Moita e Andrade (2006) states that,"the pedagogical workshops are teaching and learning situations by nature open and dynamic, which is essential in the case of public school." The pedagogical workshops were carried out in the classroom with the use of computer and Data show in the sense of clarifying the elements of the diagram, essential in the construction of knowledge, illustrated in Table 1.

Table 1:-Office Programming Gowin Diagram

\begin{tabular}{|c|c|}
\hline Thematic & Gowin Diagram \\
\hline Parts of Gowin's Diagram & $\begin{array}{l}\text { Divided into } 4 \text { parts: Events, Issue(s)-focus, Conceptual Domain and } \\
\text { Methodological Domain }\end{array}$ \\
\hline Vertex: Events & Events or phenomena of study (experiment) \\
\hline Center: Focus-Issue & Survey question related to the event. \\
\hline Question(s)-Focus & $\begin{array}{l}\text { The question that informs about the central point of the investigation. } \\
\text { Problem why?). Determines the general and specific objective of the work to } \\
\text { be studied, she directs the study, what will be investigated (For what?) }\end{array}$ \\
\hline Events & $\begin{array}{l}\text { It represents the origin of the production of knowledge to answer the } \\
\text { Question-Focus. Methodology (How?) }\end{array}$ \\
\hline $\begin{array}{l}\text { Left side: Conceptual Domain } \\
\text { (think) }\end{array}$ & $\begin{array}{l}\text { Philosophies, Theories, Principles and Concepts that allows elaborating the } \\
\text { Question-focus to give meaning to the experimentation }\end{array}$ \\
\hline Philosophy & Are the worldviews ... general objective and specific (For what?) \\
\hline Theory & $\begin{array}{lll}\text { An ordered } & \text { set of principles and concepts for the production of } \\
\text { knowledge. } & \text { - Hypotheses (maybe because) } & \text { - Theoretical basis (who } \\
\text { guarantees?) } & \text { - Methodology (how?) } & \text { - References (who guarantees?) }\end{array}$ \\
\hline Principles & $\begin{array}{l}\text { Relationship between concepts that guide and guide research. } \\
\text { Theoretical basis (who guarantees?) }\end{array}$ \\
\hline Concepts & 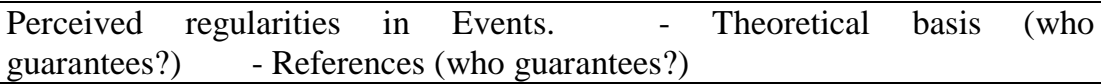 \\
\hline $\begin{array}{l}\text { Right side: } \\
\text { Methodological Domain - Making }\end{array}$ & $\begin{array}{l}\text { Record of Events, Facts, Transformation, Results, Interpretation, Assertions } \\
\text { of Knowledge (cognitive judgments) and Value Assertions about the research }\end{array}$ \\
\hline Records / Data / Facts & $\begin{array}{l}\text { Observations made on the Events, cataloged, and later attributed as facts. } \\
\text { Methodology (like?) Results }\end{array}$ \\
\hline Transformations & $\begin{array}{l}\text { Analysis of records: tables, graphs, maps, statistics, correlations records. } \\
\text { Methodology (how?) }\end{array}$ \\
\hline Knowledge Assertions & $\begin{array}{l}\text { Conclusions from the analysis of the data that answer the question (s) - focus } \\
\text { and leads to the study result }\end{array}$ \\
\hline Assertions of value & $\begin{array}{l}\text { Significance and utility about the value of research based on knowledge } \\
\text { assertions. Conclusions }\end{array}$ \\
\hline
\end{tabular}

Source:-Own authors (2018)

A total of six workshops were carried out, one in each classroom, with a duration of 55 minutes in oral presentation to make explicit the constituent elements of the diagram as well as its exploitation in the context of the Science Fair. After the completion of the pedagogical workshops, the students performed tasks related to Hydrostatics and Hydrodynamics, among others, to acquire familiarity with the heuristic instrument. With practice, students and teachers acquire familiarity with the elements of the Gowin diagram. According to Carrascosa et al. (1993) apud 
Cappelletto (2009, p.24), "is a promising way of familiarization with scientific methodology".

Works mid hair Diagram of Gowin:-

You have projected fluid and electrodynamics (Table 2) mid hair diagram foram later analyzed through a questionnaire perspective to unbelieve meanings of study.

Table 2:-Themes of the works structured from the Gowin Diagram

\begin{tabular}{|l|l|}
\hline \multicolumn{1}{|c|}{ Series } & \multicolumn{1}{c|}{ Works mediated by Gowin's Diagram } \\
\hline 1st year & - Football: a sport reducing inequalities \\
& - Eco Stand Up \\
& - The Archimedes Theorem - thrust \\
& - The Bernoulli Theorem and Venturi tube \\
& - Pressure, atmospheric pressure and density \\
& - Hydraulic press: Pascal force multiplier \\
\hline 2nd year & - Communicating vessels to determine the density of substances \\
\hline 3rd year & $\begin{array}{l}\text { - First Ohm Law in operation } \\
\text { Physics in the National High School Exam - ENEM: Sources of electricity generation }\end{array}$ \\
& - Series and parallel circuit: an experimental approach \\
\hline
\end{tabular}

Source:-Own authors (2018)

\section{Results and discussions:-}

When working with experimental activities, it is necessary to understand the aspects involved in the research, such as search processes, (re) construction of knowledge. The work done with the Gowin Diagram showed a positive strategy for infusing the methodology (Figure 2) and facilitating learning.

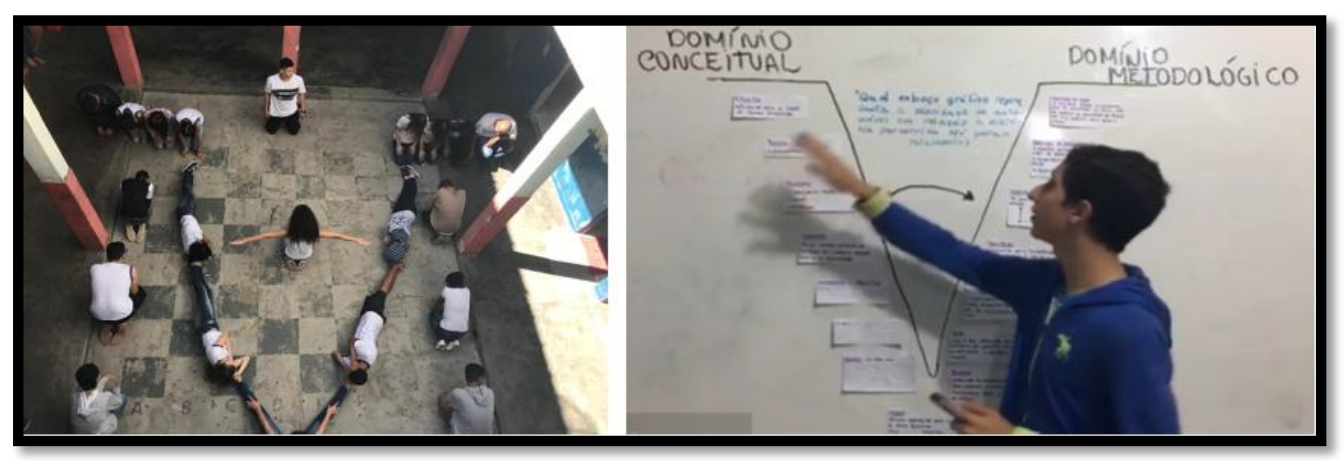

Figure 2:-Representation of the Gowin Diagram and Hydrostatic and Hydrodynamic Seminars Source:-Own authors (2018)

The 10 groups formed (Table 01), who used the Gowin Diagram in the works for the fair, first carried out the filling of the heuristic instrument with feedback from the counselor.

For Novak and Gowin (1984), Ferracioli $(2005,2018)$ and, Prado and Ferracioli (2017), the Gowin Diagram is an auxiliary tool in problem solving to understand the structure and processes of knowledge construction.

With the insertion of the Gowin heuristic in the mediation of the work of the groups of students engaged in the Science Fair, we present the answers (Graph 1) obtained from the applied questionnaire. 


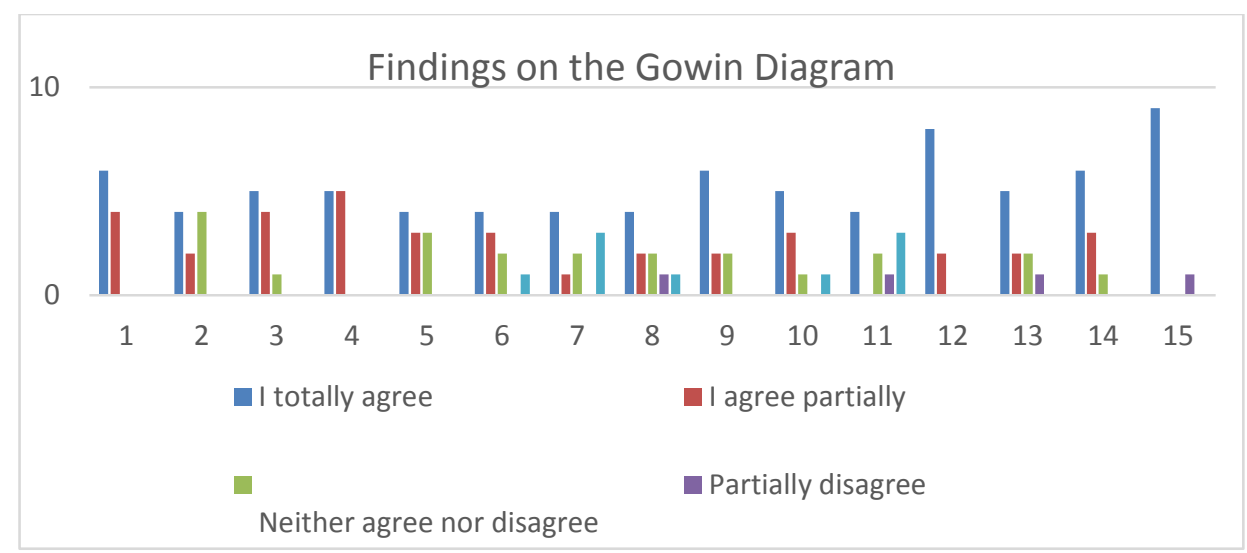

Graph 1:-Insertion of the Gowin Diagram at the Science Fair

The first question "I liked using the Gowin Diagram for Science Fair", $60 \%$ of the groups agree totally and $40 \%$ said they agree partially. Moreira (2012, pp. 3-12) points out that the Gowin Diagram is a facilitator of meaningful learning in science.

The second question, "I was more interested in the experiments than usual because the Gowin Diagram helped me to understand them better," $40 \%$ of the groups agreed totally, $20 \%$ partially agree and the other groups represent $40 \%$, nor do they agree and neither disagrees.

The third question "The Gowin Diagram helped me learn the CONCEPTS used in the experiments" 50\% agree totally, $40 \%$ agree partially and $10 \%$ neither agree nor disagree.

The fourth question, "While building the diagram, I have been able to relate the FOCUS-QUESTION to the PROCEDURES," 50\% of the groups agree totally and the other 50\% said they agree partially.

Cappelletto points out that:-

The Ve diagram can mediate the conceptual and methodological planning of the research and its practice. Since knowledge is not discovered, but constructed by people, it has a structure that can be analyzed. The See helps to identify the components of knowledge, to clarify their relations and to present them in a clear and visually compact way (CAPPELLETTO, 2009, 54)

The fifth question "It was easier to identify the DATA to be collected during the Gowin Diagram experiment", 40\% of the groups agreed totally, $30 \%$ agreed partially and the other groups represented $30 \%$, neither agree nor disagree

The sixth question, "At the beginning of the semester, I felt uncomfortable to elaborate the Gowin Diagram", 40\% totally agree, $30 \%$ disagree partially, $20 \%$ neither agree nor disagree and $10 \%$ disagree completely.

The sixth question, "At the beginning of the semester, I felt uncomfortable to elaborate the Gowin Diagram", 40\% totally agree, $30 \%$ disagree partially, $20 \%$ neither agree nor disagree and $10 \%$ disagree completely.

The seventh question 'I prefer to do the report in the Gowin Diagram format than in the initial format', $40 \%$ agree totally, $10 \%$ disagree partially, $20 \%$ neither agree nor disagree and 30\% disagree completely.

The eighth question "I felt more confident about doing the thinking side (left side) of the Gowin Diagram than the doing side (right side)," 40\% agree totally, 20\% partially agree, $20 \%$ do not agree and nor does it disagree, $10 \%$ disagree partially and $10 \%$ disagree completely.

The ninth question, "The Gowin Diagram helped me to better understand what I was doing in the experiment," $60 \%$ fully agree, $20 \%$ agree partially and another $20 \%$ neither agree nor disagree.

The Tenth Question "The Gowin Diagram helped me understand what the general purpose of the Science Fair was," $50 \%$ fully agree, $30 \%$ agree partially, $10 \%$ neither agree nor disagree, and another $10 \%$ disagree completely. 
The eleventh question, "The Gowin Diagram model had enough room to write my answers," $40 \%$ fully agree, $20 \%$ neither agree nor disagree, $10 \%$ disagree partially and 30\% disagree completely.

Question 12 "I was duly informed that I could use the Gowin Diagram during the experiment," 80\% of the groups agree totally and the other $40 \%$ said they agree partially.

Question 13: "I was comfortable using the Gowin Diagram during the experiment," 50\% fully agree, 20\% partially agree, $20 \%$ neither agree nor disagree, and $10 \%$ disagree partially.

Question 14 "I was able to get in touch with the guidance teacher whenever it was necessary," $60 \%$ of the groups agreed totally, $30 \%$ agreed partially and the other groups represented $10 \%$, neither agreed nor disagreed.

Question 15 "The willingness of the teacher to answer my questions was essential to understanding the Gowin Diagram," $90 \%$ agree fully and $10 \%$ disagree partially.

According to Gowin and Alvarez (2005) cited by Santos (2008, p. 66), the act of educating is a process of deliberate intervention in the life of students to change the meaning of their experience. From there students begin to selfeducate and thus learn to control their own experience. This change in the meaning of experience requires teacher mediation.

\section{Final Considerations:-}

From the research developed and the data collected, it was observed that the use of the Gowin Diagram represented a new methodological perspective, since the results pointed to a learning, in the field of science, full of meanings. Providing Pedagogical Workshops for students to develop skills in using the Gowin Diagram was a positive strategy in pedagogical practice. The results obtained with the questionnaire proved that the Gowin heuristic is a relevant instrument for the scientific event promoted by the school annually. Well, it leads the learner to live the scientific method in practice. The activities with Science Fair and thematic seminars mediated by the diagram generated products, socialized in the school, through the links www.wikifisica.com/seminarioand www.wikifisica.com/feira. The understanding of the importance of the Gowin diagram as an instrument that promotes an active methodology, with the purpose of taking advantage of students' scientific learning, has been left to the school community. It is believed that for the upcoming Science Fairs, there is an urgent need to practice workshops to infuse the Gowin Diagram for new students who arrive at school.

\section{Acknowledgement:-}

Capes for financial support due to the master's scholarship.

\section{References:-}

1. alves, vitória jamile lira. o fazer não pressupõe o aprender: o uso do vê de gowin no laboratório de química fundamental. 2016. disponível em: http://bdm.unb.br/handle/10483/17477>. acesso em 12 jun. 2018.

2. anastasiou, 1.g.c.; alves, 1.p. estratégias de ensinagem. in: ___ (orgs.). processos de ensinagem na universidade: pressupostos para as estratégias de trabalho em aula. 3.ed. joinville: ed. univille, 2004. p.68-100.

3. brasil. ministério da educação. secretaria de educação básica. programa nacional de apoio às feiras de ciências da educação básica fenaceb. brasília, df, 2006.

4. cappelletto, eliane o vê de gowin conectando teoria e experimentação em física geral: questões didáticas, metodológicas e epistemológicas relevantes ao processo / eliane cappelletto; orient. marco antonio moreira. 2000.

5. ferracioli, 1. o "v" epistemológico como instrumento metodológico para o processo de investigação. didática sistêmica, v.1, p.106-125. 2005. disponível no endereço: www.redisis.furg.br. acesso em: 08 fev. 2018

6. ferracioli, 1. o diagrama v no ensino experimental. 2018, publicação interna do modelab. departamento de física, universidade federal do espírito santo.

7. gowin, d.b. educating. ithaca, cornel university press, 1981.

8. moita, f. m. g. s. c; andrade, f. c. b. o saber de mão em mão: a oficina pedagógica como dispositivo para a formação docente e a construção do conhecimento na escola pública. reunião anual da anped, v. 29, p.16, 2006. 
9. moreira, m. a. diagramas v e aprendizagem significativa. revista chilena de educación científica, vol. 6, n. 2, pp. 3-12. 2007. revisado em 2012.

10. mortimer, e. f.; scott, p. h. atividade discursiva nas salas de aula de ciências: uma ferramenta sociocultural para analisar e planejar o ensino. investigações em ensino de ciências, porto alegre, ufrgs, v. 7, n. 3, p. 7, 2002.

11. novak, j. d.; gowin, d. b. aprender a aprender. lisboa: plátano edições técnicas, 1984.

12. prado, r. t. utilização do diagrama $\mathrm{v}$ em atividades experimentais de magnetismo em sala de aula de ensino médio. revista do professor de física • brasília, vol. 1, n. 1 • 2017

13. santos, s. a. (2008). la enseñanza de ciencias con un enfoque integrador a través de actividades colaborativas, bajo el prisma de la teoría del aprendizaje significativo con el uso de mapas conceptuales y diagramas para actividades demostrativo-interactivas - adi.(tese de doutorado em ensino de ciências - programa internacional de doutorado em ensino de ciências - departamento de didáticas específicas, universidade de burgos, burgos, espanha, 2008).

14. rosa, p.r.s. algumas questões relativas a feiras de ciências: para que servem e como devem ser organizada. cad. cat. ens. fís., v. 12, n. 3: p. 223-228, dez. 1995. 